\title{
Chronostratigraphy of KNM-ER 3733 and other Area 104 hominins from Koobi Fora
}

\author{
Christopher J. Lepre ${ }^{\mathrm{a}, \mathrm{b},{ }^{*}, \text { Dennis V. Kent }}{ }^{\mathrm{a}, \mathrm{b}}$ \\ ${ }^{a}$ Earth and Planetary Sciences, Rutgers University, Piscataway, NJ 08854, USA \\ ${ }^{\mathrm{b}}$ Lamont-Doherty Earth Observatory of Columbia University, Palisades, NY 10964, USA
}

\section{A R T I C L E I N F O}

\section{Article history:}

Received 21 November 2014

Accepted 16 June 2015

Available online 16 July 2015

\section{Keywords:}

Homo erectus

Early Pleistocene

Magnetostratigraphy

Olduvai Subchron

Turkana Basin

Kenya

\begin{abstract}
A B S T R A C T
A magnetostratigraphy for $\sim 60 \mathrm{~m}$ of Koobi Fora Formation sediment in Area 104 was derived from 46 oriented samples that produced well-resolved characteristic magnetizations from progressive thermal demagnetization. Approximately $59 \mathrm{~m}$ below the Morte Tuff, previously dated to $1.51 \mathrm{Ma}$ (millions of years ago), the Olduvai-Matuyama boundary ( 1.78 Ma) was found to be at the level of marker bed A2-inconsistent with the Area 102 type section and thus contrary to fossil dating schemes that utilize temporal equivalence between A2 [104] and A2 [102]. The magnetostratigraphic data, coupled with the Morte Tuff, provide a means to interpolate new ages for marker beds A2 [104] and the White Tuff, as well as multiple Area 104 hominin fossils. Noteworthy is the new date of $\sim 1.63$ Ma for KNM-ER 3733, which now implicates KNM-ER 2598 as the sole early African Homo erectus fossil demonstrably older than Dmanisi and Java Homo specimens. Re-dating KNM-ER 3733 creates a 300-kyr gap at 1.9 to 1.6 Ma in the African fossil record of $H$. erectus, which might be partially spanned by hand axes recently dated at $\sim 1.76 \mathrm{Ma}$, if the Acheulian is indeed proprietary to this species.
\end{abstract}

(C) 2015 Elsevier Ltd. All rights reserved.

\section{Introduction}

Fossil evidence for the origins of the genus Homo is incompletely understood. Part of this issue stems from the inability, in many cases, to directly date the fossils or sediments from which they derive and the need to refine the chronology of East African rift valley geological sequences. Such complications have contributed to debates over the evolutionary relationships, number of species, and paleobiology for Early Pleistocene Homo (Wood, 1991; Antón, 2003, 2012; Spoor et al., 2007; Wood, 2011; Wood and Baker, 2011; Leakey et al., 2012; Lordkipanidze et al., 2013). Important to these debates are the sedimentary successions of northeast Turkana Basin in Kenya (Fig. 1) especially from the PliocenePleistocene Koobi Fora Formation (Fig. 2). Fossils recovered from this formation represent some of the earliest known evidence for the genus Homo (Leakey and Leakey, 1978).

Collection Area 104 of the Koobi Fora region has been exceptional for providing fossil evidence of hominin evolution, as many fossil specimens from multiple taxa have been recovered from here (Leakey and Leakey, 1978; Feibel et al., 1989; Wood, 1991). An

\footnotetext{
* Corresponding author.

E-mail address: lepre@ldeo.columbia.edu (C.J. Lepre).
}

important stratigraphic level in the central portion of Area 104 is the A2 marker bed. This has been used as a key bed to correlate the sedimentary successions and infer dates for many hominin fossils from both Area 104 and the Koobi Fora region (Tindall, 1985; Feibel et al., 1989; Brown et al., 2006; Gathogo and Brown, 2006; Lepre and Kent, 2010; McDougall et al., 2012). A2 originally was defined from deposits in Area 102 (Brown and Feibel, 1986, 1991). However, as discussed in this paper, we do not believe that this bed is the same stratigraphic unit in Area 104 as the unit defined in Area 102, and for this reason we refer to the beds as A2 [104] and A2 [102], respectively. In both areas the bed is an arenaceous bioclastic carbonate principally distinguished by a multitude of Lockeia (clam burrows in life position) trace fossils (Tindall, 1985; Feibel et al., 1989). Approximately 16 hominin fossils have been located from outcrop levels that are situated near A2 [104] (Tindall, 1985; Feibel et al., 1989), notably hominin fossil KNM-ER 3733, which was discovered in situ within sediments of central Area 104 (Leakey and Leakey, 1978).

KNM-ER 3733, a rare example of a nearly complete cranium, is regarded as one of the geologically oldest representative fossils of early African Homo erectus (Leakey and Leakey, 1978; Wood, 1991; Antón, 2003, 2012; Spoor et al., 2007; Wood and Baker, 2011; Leakey et al., 2012). However, the geological age of KNM-ER 3733 has been a subject of debate because of changing interpretations 


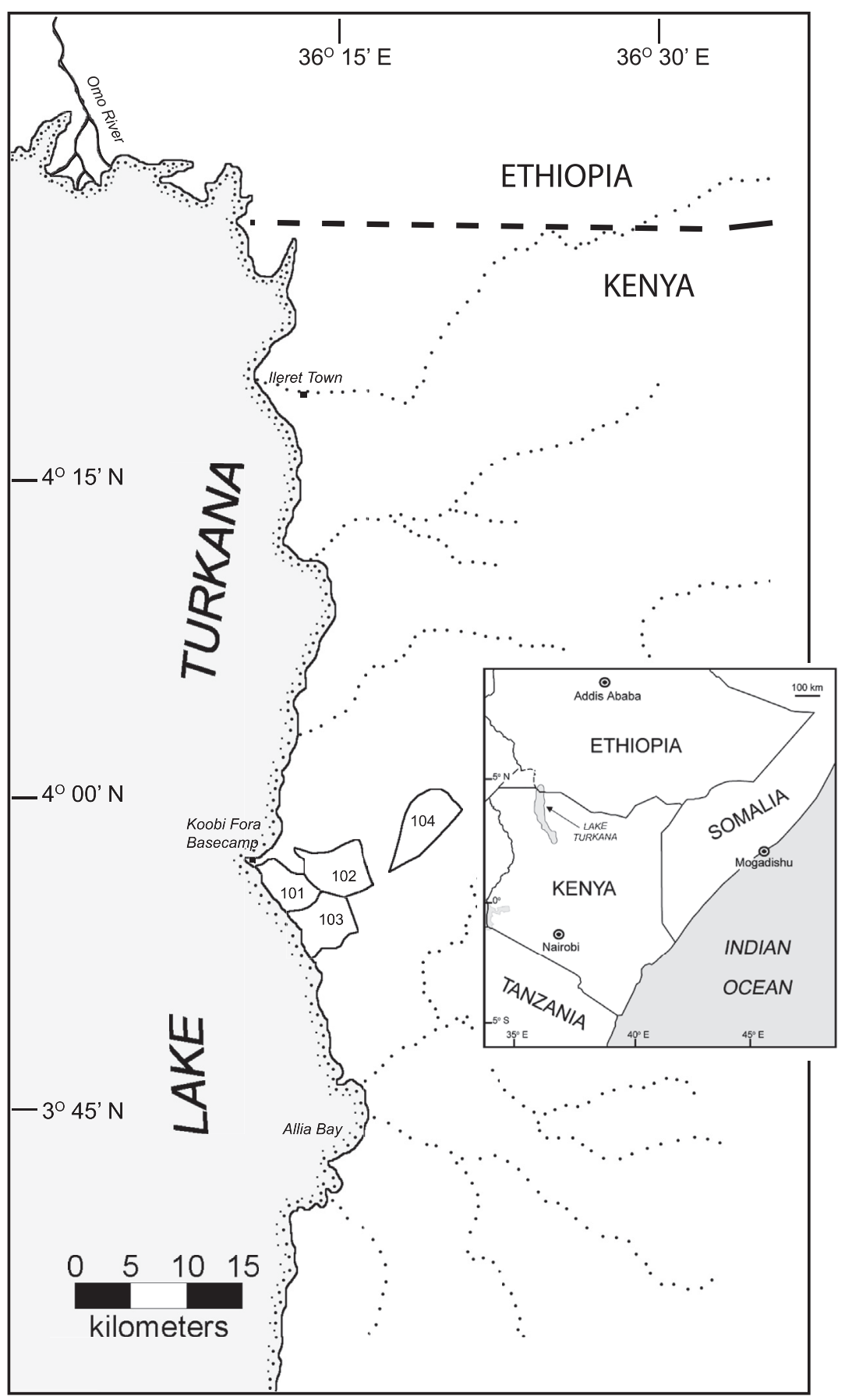

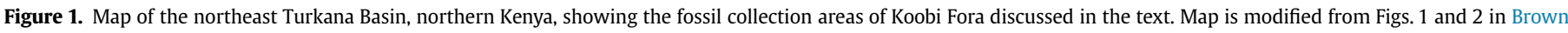
and Feibel (1986).

over the stratigraphy of the KBS Member (Fig. 3). Using data reported by Hillhouse et al. (1977, 1986), Feibel et al. (1989) and McDougall et al. (1992) placed the top of the Olduvai Subchron in the type section of the KBS Member from collection Area 102 at approximately $60 \mathrm{~m}$ above the stratigraphic level of the KBS Tuff and $7 \mathrm{~m}$ below A2 [102]. Feibel et al. (1989) used the position of the top of the Olduvai Subchron to estimate an age of $\sim 1.78 \mathrm{Ma}$ (millions of years ago) for A2 in the entire Koobi Fora Formation, and reported that the stratigraphic level of KNM-ER 3733 was $6 \mathrm{~m}$ above A2 [104]. Accordingly, the geological age of KNM-ER 3733, and other hominin fossils with stratigraphic positions near A2 in the entire Koobi Fora Formation, was determined to be $\sim 1.78 \mathrm{Ma}$ (Feibel et al., 1989) (Panel A, Fig. 3).

Brown et al. (2006) used tephrochronology to reinterpret the position of the top of the Olduvai Subchron in the type section of the KBS Member at $\sim 25 \mathrm{~m}$ above the KBS Tuff or $\sim 35 \mathrm{~m}$ below A2 [102] (Panel B, Fig. 3). Gathogo and Brown (2006) stated that the White Tuff, with an estimated (interpolated) age of $1.63 \mathrm{Ma}$ (Brown et al., 2006), is the nearest unequivocally identified marker level in Area 104 that is near (<300 m geographically and $\sim 8 \mathrm{~m}$ above 


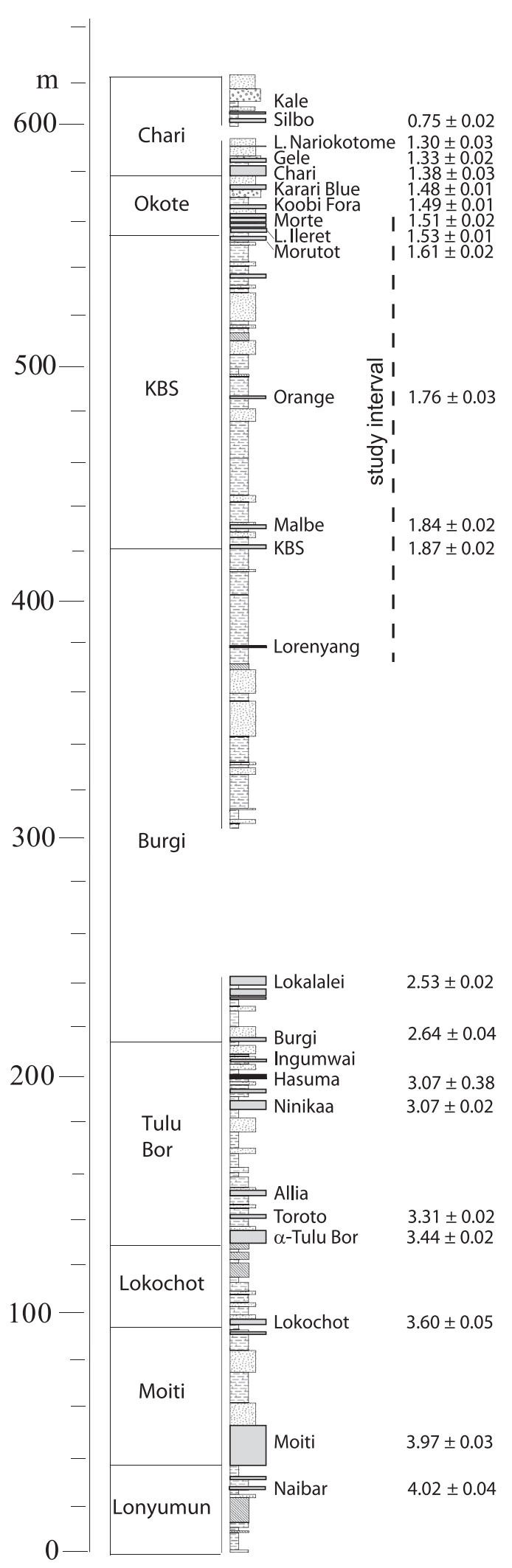

Figure 2. Koobi Fora Formation lithostratigraphy and nomenclature, with radiometrically determined ages of member-defining tuffs included for reference. From McDougall et al. (2012). Note unconformities (missing section) in the Chari and Burgi members. stratigraphically) the KNM-ER 3733 site, and thus the fossil could be $\sim 130$ kyr younger (Panel B, Fig. 3) than the date of $\sim 1.78 \mathrm{Ma}$ interpreted by Feibel et al. (1989).

McDougall et al. (2012) linearly interpolated the age of the White Tuff in Area 104 at 1.60 Ma, using Lepre and Kent's (2010) age of $1.71 \mathrm{Ma}$ for $\mathrm{A} 2$ [102] and the radioisotopic date of $1.510 \pm 0.016 \mathrm{Ma}$ (all formal uncertainties quoted at $1 \sigma$ unless otherwise noted) for the Morte Tuff (McDougall and Brown, 2006) (Panel C, Fig. 3). In Area 104 McDougall et al. (2012) located the KNM-ER 3733 hominin site some $230 \mathrm{~m}$ to the NW of a tuff designated by Tindall (1985) as T9b, which Brown and Feibel (1986) and Brown et al. (2006) correlated with the White Tuff. McDougall et al. (2012) interpreted that the excavation site for KNM-ER 3733 is about $1.5 \mathrm{~m}$ below the base of the White Tuff and suggested an age of 1.65 Ma for the fossil (Panel C in Fig. 3).

To better assess the dates of the hominin fossils and the correlations with the type section of the KBS Member in Area 102, we provide a new magnetostratigraphy for Area 104. This allows us to place the hominin fossils that had been found there within a more direct chronologic framework and to discuss some implications of the refined stratigraphy.

\section{Materials and methods}

Koobi Fora Formation sediments in central Area 104 are exposed along a series of sparsely vegetated badlands. Gullies provide most of the sedimentary exposure, as north/northwest trending ephemeral streams erode the landscape. A majority of the sampled outcrops and hominin fossils derive from the western part, whereas the KNM-ER 3733 site is in the eastern part of central Area 104 (Fig. 4).

Outcrops largely consist of successions of inter-layered mudstone and sandstone, with minor occurrences of tuff, altered tuff (bentonite), conglomerate, and arenaceous bioclastic carbonates that consist of stromatolites, gastropods, and mollusks. These deposits accumulated along the margins of a large paleo-lake (Lepre, 2014), for which the depositional environments have been previously described and interpreted (Lepre et al., 2007). A majority of the Area 104 section has been allocated to the upper Burgi, KBS, and Okote Members of the Koobi Fora Formation (Figs. 2 and 3), which is based on the occurrence of the volcaniclastic markers named the Lorenyang Tuff, White Tuff, and Morte Tuff (Tindall, 1985; Brown and Feibel, 1986; Brown et al., 2006; McDougall et al., 2012). Of these, the Morte Tuff is the only one radiometrically dated $\left({ }^{40} \mathrm{Ar} /{ }^{39} \mathrm{Ar}\right)$ and has an eruptive age of $1.510 \pm 0.016 \mathrm{Ma}$ (McDougall and Brown, 2006).

At some locations, faulting is evident from the tilting of beds with dip slopes in the range of $3-10^{\circ}$. Most faults are normal as mapped by Tindall (1985). Of importance are the NE/SW trending faults that cut across the central part of the Area 104 study area (Fig. 4). Faulting has uplifted lower/older strata on the western side and down-dropped upper/younger strata on the eastern side.

Marker beds and measured sections were investigated according to the stratigraphy and maps of Tindall (1985) in Area 104. Finegrained strata were targeted for sample collection, beginning at the Lorenyang Tuff and working upward through the $\sim 57 \mathrm{~m}$ of section to the level of the White Tuff (Fig. 3 all panels). A total of 55 samples were collected as hand-sized blocks on which azimuth and dips were scribed on planed surfaces before removal from the outcrop. The cement pillar marking the KNM-ER 3733 fossil site was still in place as of June 2011. Four samples (KNM-ER3733a, b, c and d) were collected from a mudstone lens interbedded with sands of the fossil excavation site. 


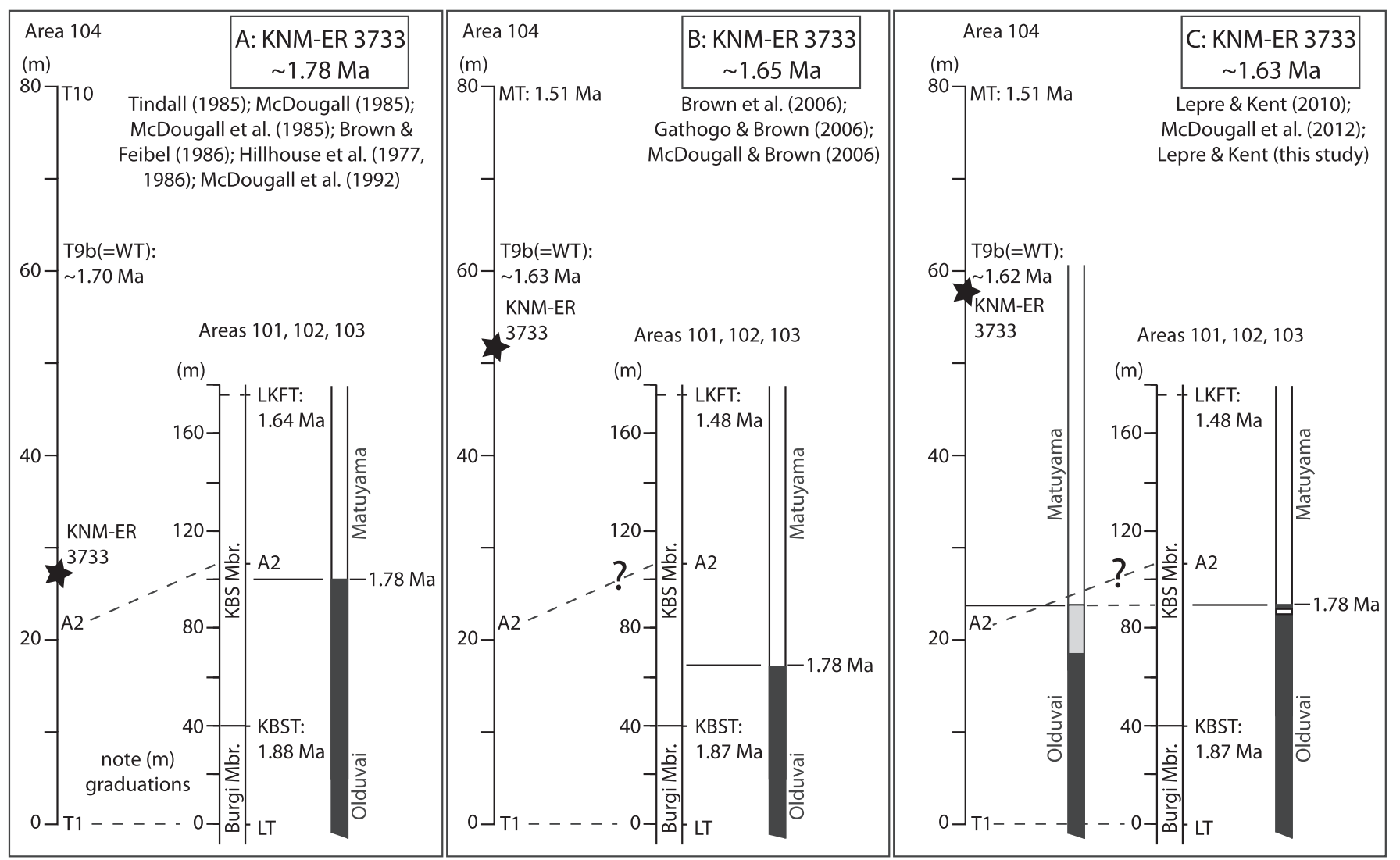

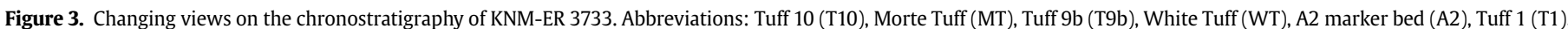

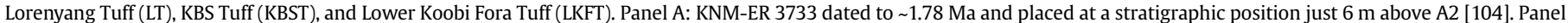

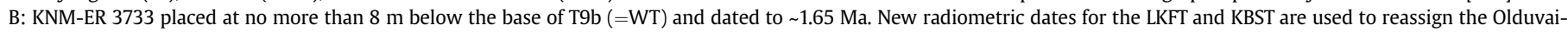

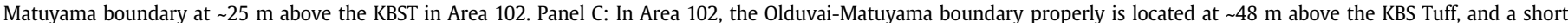

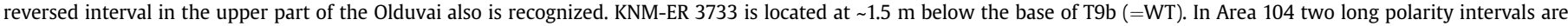

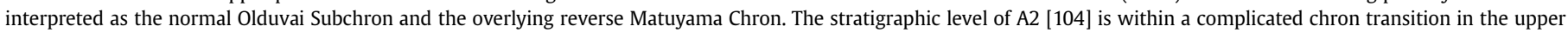

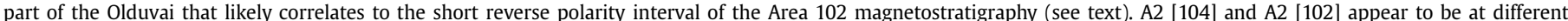
magnetostratigraphic levels. We suggest an estimated age of 1.63 Ma for KNM-ER 3733.

Hand-cut blocks were reduced to $\sim 10$ cc cubic specimens for paleomagnetic experiments. The natural remanent magnetization (NRM) was measured for all specimens using the $2 \mathrm{G}$ Model $760 \mathrm{DC}$ SQUID rock magnetometer in the shielded room of the Paleomagnetics Laboratory of Lamont-Doherty Earth Observatory (Columbia University, NY, U.S.A.). Progressive thermal demagnetization (TD) was applied to specimens for identifying magnetization components. The TD protocol involved five steps at $100{ }^{\circ} \mathrm{C}$ intervals $\left(100-500{ }^{\circ} \mathrm{C}\right)$ and three steps at $25^{\circ} \mathrm{C}$ intervals $\left(525-575{ }^{\circ} \mathrm{C}\right)$. Results of the demagnetization experiments are listed in Table 1. Magnetic susceptibility values were determined with a Bartington MS2B instrument for each specimen initially and after each TD step to monitor any magneto-chemical alteration. To help constrain the bulk magnetic mineralogy of the sediments, back-field isothermal remanent magnetization (IRM) curves were generated for chips from five undemagnetized specimens by giving them an IRM in $2.5 \mathrm{~T}$ and then in progressively higher direct fields to $2.5 \mathrm{~T}$ in the opposite direction.

\section{Results and discussion}

\subsection{Results of the magnetic measurements}

Measured specimens were strongly magnetized, with an average NRM of $130 \mathrm{~mA} / \mathrm{m}$ (range from about 2 to $750 \mathrm{~mA} / \mathrm{m}$ ). The main carrier of the magnetization was most probably magnetite, given that the NRM was typically reduced to less than $10 \%$ by $575^{\circ} \mathrm{C}$, which is near the Curie point of this mineral. Magnetite of similar, albeit varying, concentrations was also indicated by the back-field IRM curves, which showed remanent coercivities of less than $500 \mathrm{mT}$ and an approach to saturation IRM by $\sim 0.2 \mathrm{~T}$, although small gradual increases in IRM to much higher fields suggested some contributions from a higher coercivity mineral like hematite (Fig. 5).

For the 46 accepted specimens a stable component interpreted as the characteristic remanent magnetization (ChRM) was identified from a linear demagnetization trajectory that trends toward the origin of orthogonal plots after the removal of viscous components by around $300{ }^{\circ} \mathrm{C}$ (Fig. 6). These had maximum angular deviation (MAD) values of less than $15^{\circ}$, calculated from principal component analyses (e.g., Kirschvink, 1980) of data from TD steps $400{ }^{\circ} \mathrm{C}, 500{ }^{\circ} \mathrm{C}, 525^{\circ} \mathrm{C}$, and $550{ }^{\circ} \mathrm{C}$ (Table 1 ). This temperature range was selected to represent the ChRM because it offered the most number of steps that produced the fewest number of specimens rejected for large MAD values (for example, nine rejects as compared to 17 rejects with TD steps of $500{ }^{\circ} \mathrm{C}, 525^{\circ} \mathrm{C}, 550{ }^{\circ} \mathrm{C}$ $575^{\circ} \mathrm{C}$, and 12 rejects with TD steps of $500{ }^{\circ} \mathrm{C}, 525^{\circ} \mathrm{C}, 550{ }^{\circ} \mathrm{C}$ ).

The mean ChRM directions for the 46 accepted samples separated into northerly and southerly groups (Fig. 7). Northerly and shallow (normal polarity) directions had a mean direction of 


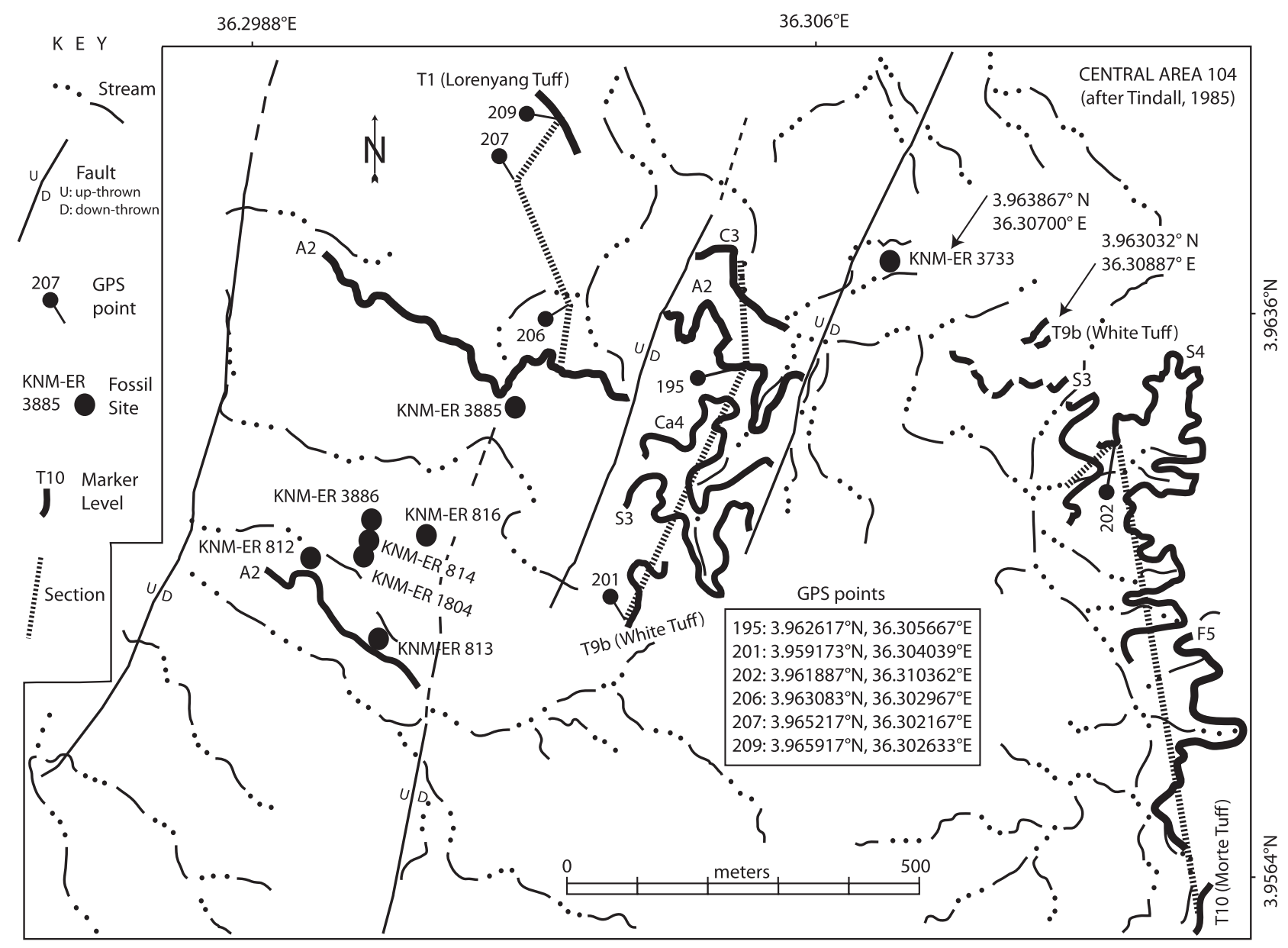

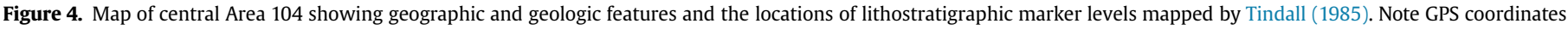
and placement of hominin fossil sites. Transects of examined sections after Tindall (1985) and reinvestigated during 2011 fieldwork.

$\mathrm{D}=1.8^{\circ} \mathrm{I}=4.3^{\circ}\left(\mathrm{k}=17.0\right.$, alpha95 $\left.=7.6^{\circ}, n=23\right)$, whereas the southerly and shallow (reverse polarity) directions had a mean direction of $\mathrm{D}=177.2^{\circ} \mathrm{I}=-6.5^{\circ}\left(\mathrm{k}=29.1\right.$, alpha95 $\left.=5.7^{\circ}, n=23\right)$. These data passed a reversal test, classified as $\mathrm{Rb}$ (observed gamma $=5.1^{\circ}$, critical gamma $=12.9^{\circ}$ ) according to the criteria of McFadden and McElhinny (1990). After inverting the directions to common (normal) polarity, the overall mean direction was $\mathrm{D}=359.5^{\circ} \mathrm{I}=5.4^{\circ}\left(\mathrm{k}=21.5\right.$, alpha95 $\left.=4.6^{\circ}\right)$, which was only marginally (but not significantly) shallower than the expected geocentric axial dipole field for the locality $\left(\mathrm{D}=0^{\circ} \mathrm{I}=8^{\circ}\right)$.

\subsection{Magnetostratigraphic interpretations}

Virtual geomagnetic pole (VGP) latitudes derived from sample ChRM directions plotted against stratigraphic thickness revealed two polarity intervals between and inclusive of the White Tuff and Lorenyang Tuff (Fig. 8 and Table 1). The lower $\sim 20 \mathrm{~m}$ of section from below the base of A2 [104] down to and including the Lorenyang Tuff was characterized by positive VGP latitudes (shallow and northerly ChRM directions), which reflect an interval of normal polarity. The overlying $40 \mathrm{~m}$ interval from above A2 [104] up to and including the White Tuff was characterized by negative VGP latitudes (Fig. 8 and Table 1 ) that signify reverse polarity (shallow and southerly ChRM directions) (Fig. 6).

The radioisotopic date for the Morte Tuff of $1.510 \pm 0.016 \mathrm{Ma}$ (McDougall and Brown, 2006) provides a key constraint for correlation of the Area 104 magnetostratigraphy to the Geomagnetic Polarity Time Scale (Fig. 8): the lower $\sim 20 \mathrm{~m}$ of normal polarity most probably corresponds to the younger portion of the Olduvai Subchron (C2n) and the upper $40 \mathrm{~m}$ of reverse polarity with the succeeding portion of the Matuyama Chron (C1r.2r).

Previous work in the northwest Turkana Basin (Lepre et al., 2011) found a more structured character for the Olduvai to Matuyama transition, which had also been observed in Area 102 of Koobi Fora (Lepre and Kent, 2010) and several other highresolution records (e.g., Ninkovich et al., 1966; Clement and Kent, 1987; Heller et al., 1991; Tric et al., 1991; Holt and Kirschvink, 1995; Kidane et al., 2003). In fact, the magnetostratigraphy of the former Global Boundary Stratotype Section and Point for the Pliocene-Pleistocene boundary in outcrops of marine sapropel sequences from Vrica, Italy (Tauxe et al., 1983; Zijderveld et al., 1991) has been depicted in some astronomically tuned polarity time scales to include a $\sim 30-\mathrm{kyr}$ interval of indeterminate polarity at the termination of the Olduvai (see Fig. 2 in Lourens et al., 2004).

A more structured character of the Olduvai to Matuyama transition also appears to be recorded by Area 104 sediments within a $6-\mathrm{m}$ interval associated with the reversal boundary (Fig. 8). This was inferred from the data of five specimens $(104-53,-55,-56,-57$, -58 ) categorized as poorly resolved because of MAD values $>15^{\circ}$. Stepwise thermal demagnetization of these specimens revealed the 
Table 1

Paleomagnetic data for samples from the Area 104 section.

\begin{tabular}{|c|c|c|c|c|c|}
\hline Level $(\mathrm{m})^{\mathrm{a}}$ & Sample & $\operatorname{MAD}\left({ }^{\circ}\right)$ & $\operatorname{Dec}\left({ }^{\circ}\right)$ & $\operatorname{Inc}\left({ }^{\circ}\right)$ & VGP lat $\left(^{\circ}\right)$ \\
\hline 0 & 104-39a & 2.3 & 359.5 & -1.2 & 85.4 \\
\hline 1.5 & $104-40$ & 2.5 & 31.3 & 3.8 & 58.7 \\
\hline 2.5 & $104-41$ & 5.2 & 13.3 & 3.5 & 76.5 \\
\hline 3.5 & $104-42$ & 12.7 & 23.0 & -3.1 & 66.4 \\
\hline 4.5 & $104-43$ & 4.5 & 6.4 & -2.9 & 81.6 \\
\hline 5.5 & $104-44 a$ & 2.9 & 358.6 & -3.6 & 84.0 \\
\hline 6.5 & $104-31$ & 4.5 & 0.8 & -3.9 & 84.0 \\
\hline 6.5 & $104-45$ & 2.2 & 2.0 & 4.5 & 87.3 \\
\hline 7.5 & $104-32$ & 2.8 & 6.3 & -17.9 & 75.4 \\
\hline 7.5 & $104-46$ & 9.2 & 7.1 & 1.1 & 82.1 \\
\hline 8.5 & $104-33 a$ & 6.5 & 2.7 & 7.2 & 87.3 \\
\hline 8.5 & $104-47$ & 9.1 & 351.2 & 27.3 & 76.4 \\
\hline 9.5 & $104-34$ & 4.2 & 5.6 & 23.3 & 80.1 \\
\hline 9.5 & $104-48$ & 4.2 & 0.1 & -12.2 & 79.8 \\
\hline 10.5 & $104-35$ & 3.4 & 355.2 & 12.7 & 84.6 \\
\hline 11.5 & $104-36$ & 2.5 & 358.2 & 17.0 & 85.0 \\
\hline 14.5 & $104-49 a$ & 1.2 & 359.6 & 7.2 & 89.4 \\
\hline 15.5 & $104-50$ & 1.6 & 0.1 & -6.7 & 82.6 \\
\hline 16.5 & $104-51$ & 1.8 & 7.5 & -0.4 & 81.4 \\
\hline 16.5 & $104-52$ & 7.1 & 355.8 & 9.9 & 85.7 \\
\hline 17.5 & $104-53$ & 42.1 & 225.3 & -9.8 & -44.8 \\
\hline 18.5 & $104-55$ & 29.7 & 26.2 & -6.0 & 62.9 \\
\hline 19.5 & $104-54$ & 6.9 & 6.5 & 11.8 & 83.2 \\
\hline 20.5 & $104-56$ & 20.6 & 348.0 & -5.2 & 76.3 \\
\hline 21.5 & $104-57$ & 17.8 & 340.0 & -15.9 & 66.7 \\
\hline 22.5 & $104-58$ & 18.2 & 31.2 & 20.2 & 58.4 \\
\hline 23.5 & $104-1$ & 2.3 & 176.4 & -2.3 & -85.4 \\
\hline 24.5 & $104-2$ & 3.8 & 177.6 & -11.2 & -87.1 \\
\hline 25.5 & $104-3 a$ & 8.9 & 181.9 & 2.8 & -84.3 \\
\hline 27.0 & $104-4$ & 5.0 & 170.7 & -5.7 & -80.6 \\
\hline 28.5 & $104-5$ & 4.9 & 184.1 & -10.9 & -85.6 \\
\hline 29.5 & $104-6$ & 4.8 & 187.6 & -7.8 & -82.4 \\
\hline 30.5 & $104-7$ & 6.0 & 181.1 & -7.3 & -88.9 \\
\hline 31.5 & $104-8$ & 4.4 & 2.5 & 20.5 & 83.0 \\
\hline 32.5 & $104-9$ & 34.5 & 46.4 & 39.9 & 41.4 \\
\hline 33.5 & $104-10$ & 15.3 & 136.2 & 28.0 & -42.7 \\
\hline 34.5 & $104-11$ & 3.0 & 168.2 & -0.5 & -77.6 \\
\hline 35.5 & $104-12$ & 4.6 & 156.4 & -6.8 & -66.4 \\
\hline 36.0 & $104-13$ & 15.0 & 354.2 & -0.1 & 82.9 \\
\hline 37.5 & $104-14$ & 6.6 & 173.1 & -13.8 & -82.5 \\
\hline 38.5 & 104-15 & 10.8 & 182.6 & -15.4 & -85.4 \\
\hline 39.5 & $104-16$ & 10.9 & 186.1 & -15.5 & -82.8 \\
\hline 40.5 & $104-17$ & 7.6 & 184.7 & -3.6 & -84.8 \\
\hline 42.0 & $104-18$ & 11.0 & 165.2 & 10.1 & -72.6 \\
\hline 43.0 & $104-20$ & 11.8 & 169.8 & 0.7 & -78.9 \\
\hline 44.0 & $104-21 a$ & 2.6 & 160.4 & 14.1 & -67.5 \\
\hline 46.0 & $104-30$ & 12.0 & 294.2 & -2.1 & 24.1 \\
\hline 50.0 & $104-22$ & 5.1 & 176.5 & 0.8 & -84.4 \\
\hline 50.5 & $104-23$ & 4.8 & 169.6 & -4.4 & -79.5 \\
\hline 51.0 & $104-24$ & 2.4 & 189.4 & -19.7 & -78.8 \\
\hline 52.0 & $104-25$ & 7.6 & 185.1 & -2.2 & -84.1 \\
\hline 52.5 & $104-26$ & 40.8 & 10.7 & -46.6 & 56.5 \\
\hline 53.5 & $104-27$ & 8.9 & 178.4 & 3.4 & -84.1 \\
\hline 55.0 & $104-29 a$ & 4.0 & 184.3 & -7.7 & -85.7 \\
\hline 56.5 & $104-28 a$ & 1.5 & 190.9 & -48.1 & -62.8 \\
\hline
\end{tabular}

${ }^{a}$ Level $(\mathrm{m})$ is the stratigraphic height in meters from base of the Lorenyang Tuff. Thermal demagnetization steps $400^{\circ}, 500^{\circ}, 525^{\circ}$, and $550^{\circ} \mathrm{C}$ were used to isolate the ChRM direction (Dec, declination, and Inc, inclination, in bedding coordinates), and corresponding VGP latitude, positive for northern and negative for southern, using Principal Component Analysis over thermal treatments giving MAD, maximum angular deviation. Samples with MAD values larger than $15^{\circ}$ indicative of lowerquality data were not used for magnetostratigraphic interpretations or Fisher statistics.

usual normal polarity overprint to $400{ }^{\circ} \mathrm{C}$, which in these samples masked an ill-defined and weakly developed component at $400-575{ }^{\circ} \mathrm{C}$. The high unblocking temperature component might be indicative of a reverse (e.g., specimen 104-53 in Figs. 6 and 8) or normal (e.g., specimen 104-58 in Figs. 6 and 8) polarity direction. Accordingly, we placed the Olduvai-Matuyama reversal boundary at $\sim 23 \mathrm{~m}$, midway between stratigraphic positions of the uppermost nominally normal, albeit poorly, resolved specimen (i.e., 104-58) and the lowermost, well-resolved, reverse specimen (i.e., 104-1).

\subsection{Age model for Area 104}

As initially defined (Brown and Feibel, 1986), lithostratigraphic members of the Koobi Fora Formation are units delimited by the positions of tuffs in a designated type section (Fig. 2). The radioisotopic dating of the tuffs adds an informal age range to a member's definition (McDougall et al., 2012). The base of the Okote Member is formally defined by the Okote Tuff (Brown and Feibel, 1986) that has an interpolated age of $1.56 \mathrm{Ma}$ with an estimated uncertainty of $0.05 \mathrm{Myr}$ (McDougall and Brown, 2006). However, the top of the underlying KBS Member is defined by the Lower Koobi Fora Tuff-radioisotopically dated to $1.476 \pm 0.013 \mathrm{Ma}$ (McDougall and Brown, 2006)-because the Okote Tuff is not preserved within the outcrops of this member's type or reference sections (e.g., 102-11 and 103-1 in Fig. 6 of Brown and Feibel, 1986). The Morte Tuff with a radioisotopic date of $1.510 \pm 0.016 \mathrm{Ma}$ (McDougall and Brown, 2006) provides a means to recognize the presence of Okote Member strata in Area 104 (Brown et al., 2006). These strata are about $0.034 \mathrm{Myr}$ older than the Lower Koobi Fora Tuff and 0.050 Myr younger than the interpolated age of the Okote Tuff (Fig. 9).

The boundary between the Burgi and KBS Members in Area 104 is also difficult to assess because of the absence of the KBS Tuff or a tuff with a chronostratigraphic position that is similar to the KBS. At the type section of the KBS Member in Area 102, the KBS Tuff lies approximately $48 \mathrm{~m}$ beneath the top of the Olduvai Subchron, which is in the KBS Member, and $\sim 40 \mathrm{~m}$ above the Lorenyang Tuff, which is in the Burgi Member (Brown and Feibel, 1986; Lepre and Kent, 2010). The Lorenyang Tuff in Area 104 is anchored to its estimated age of 1.90 Ma that is derived from linear interpolation between the base of the Olduvai Subchron and the KBS Tuff (cf., Joordens et al., 2011) in the Area 102 type section (Fig. 9). At $\sim 5 \mathrm{~m}$ above the Lorenyang Tuff in Area 104, the stratigraphic position corresponding to the KBS Tuff's radioisotopic date of $1.869 \mathrm{Ma}$ is conditionally placed, which allows for an inferred correlation for the top/base of the Burgi/KBS Member in Area 104 and facilitates a chronological correlation with the member-defining boundary in the Area 102 type section (Fig. 9).

A2 [104] lies within the transitional zone for the OlduvaiMatuyama boundary, and thus is effectively dated at $1.78 \mathrm{Ma}$ (Fig. 8). McDougall et al. (2012) estimated an age of $1.60 \mathrm{Ma}$ for the White Tuff in Area 104 based on linear interpolation between the radioisotopic date of the Morte Tuff from Area 104 $(1.510 \pm 0.016 \mathrm{Ma}$; McDougall and Brown, 2006) and the estimated age of 1.71 Ma for A2 [102] (Lepre and Kent, 2010). Our results derive a linearly interpolated age of 1.62 Ma for the White Tuff in Area 104 (Fig. 9) in very good agreement with the age of $1.63 \mathrm{Ma}$ reported by Brown et al. (2006) as well as 1.60 Ma reported by McDougall et al. (2012).

\subsection{Interpolated ages for hominin fossils from Area 104}

McDougall et al. (2012) place KNM-ER 3733 at $1.5 \mathrm{~m}$ below the White Tuff, which is $\sim 35 \mathrm{~m}$ above A2 [104]. Our paleomagnetic results obtained from the four samples (KNM-ER 3733a, b, c, and d) collected at the KNM-ER 3733 fossil site indicate reverse polarity directions (Fig. 6). These results are consistent with our magnetostratigraphic framework that shows reverse polarities for the White Tuff and the $\sim 40 \mathrm{~m}$ of sediment beneath this tuff (Fig. 8 and Table 1). We interpret that the KNM-ER 3733 fossil was recovered from sediments carrying a reverse magnetic polarity indicative of the 

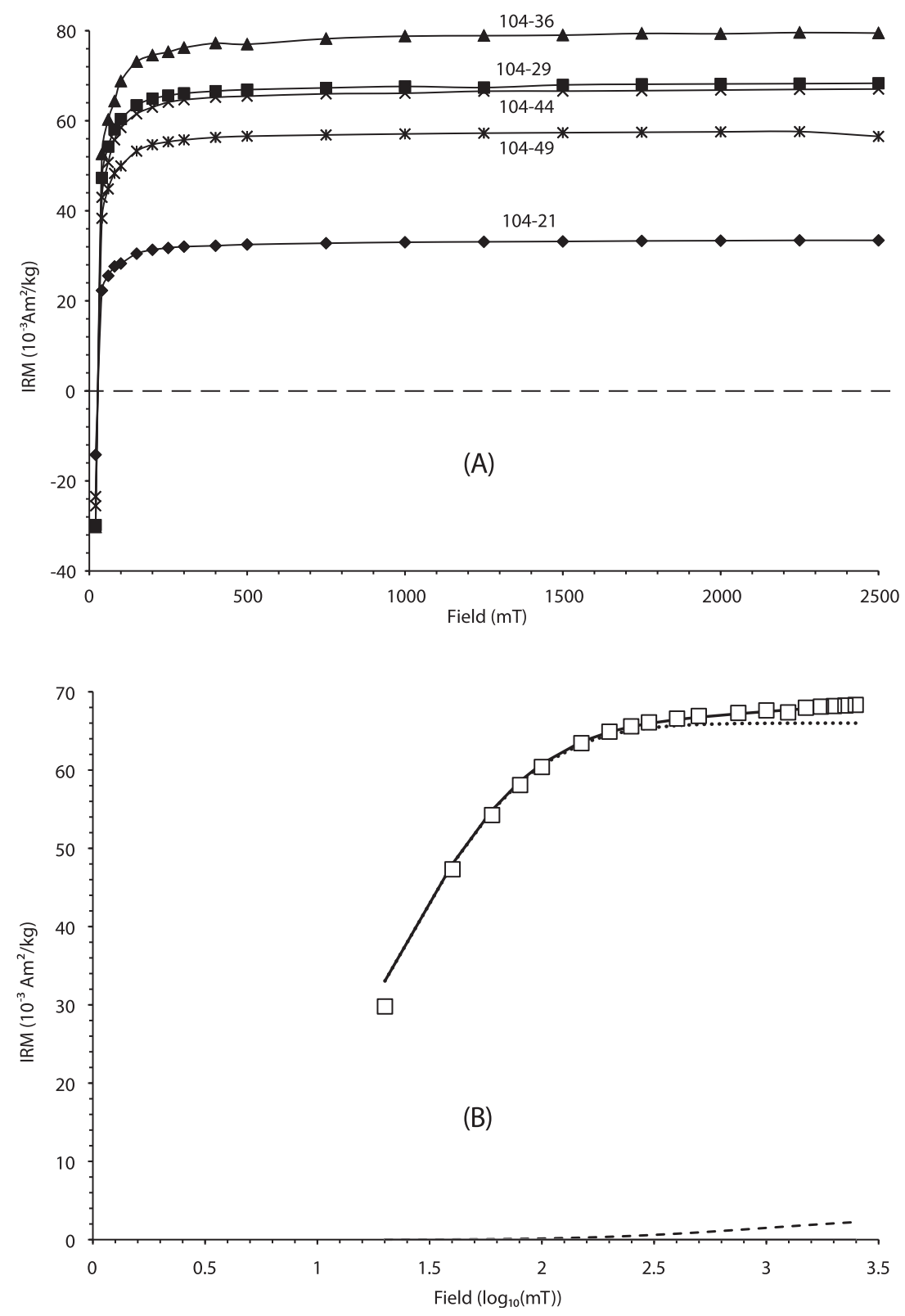

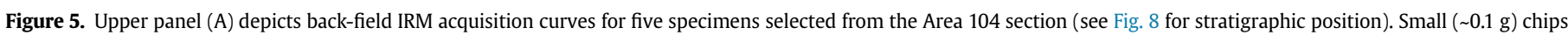

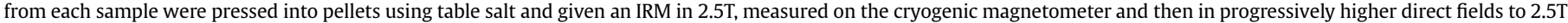

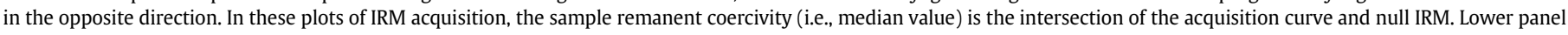

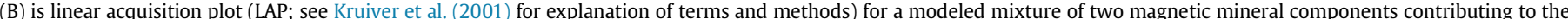

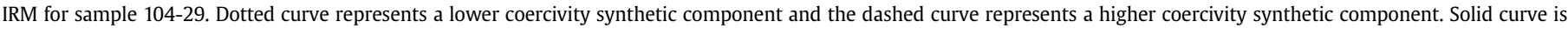

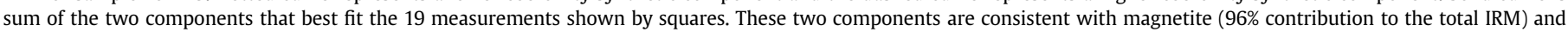
hematite ( $4 \%$ contribution to the total IRM).

(C1r.2r) Matuyama Chron (Panel C in Figs. 3, 8 and 9). Therefore, KNM-ER 3733 is younger than the top of the Olduvai Subchron, i.e., $<1.78 \mathrm{Ma}$, but older than the Morte Tuff (1.51 Ma). Linear interpolation of sediment accumulation rates between these dated horizons resolves an age of 1.63 Ma for KNM-ER 3733 (Fig. 9).

Several fossils have stratigraphic positions within $4 \mathrm{~m}$ beneath the base of A2 [104] (Figs. 4 and 8) and therefore also date to 1.78 Ma. These include (after Wood, 1974; Leakey and Leakey, 1978; Wood, 1991; Wood and Constantino, 2007): KNM-ER 814 (vault fragments), KNM-ER 813 (talus), KNM-ER 812 (mandible fragment), KNM-ER1804 (mandible fragment), KNM-ER 3885 (isolated tooth), and KNM-ER 3886 (isolated tooth). These five fossils from Area 104 represent some of the best age-constrained hominins in the formation because they effectively are at the stratigraphic level of the Olduvai-Matuyama boundary dated to $1.78 \mathrm{Ma}$.

\subsection{Implications for $\mathrm{H}$. erectus}

Because of the anatomical incompleteness and rarity of Early Pleistocene hominin fossils, perceptions about the human evolutionary lineage can change dramatically when new specimens are found or the geologic ages of previously discovered ones are revised. Both new fossils and revised dates have led to debates about where and when $H$. erectus sensu lato first evolved (Swisher et al., 1994; Gabunia et al., 2000; Antón, 2003, 2012; Dennell and 

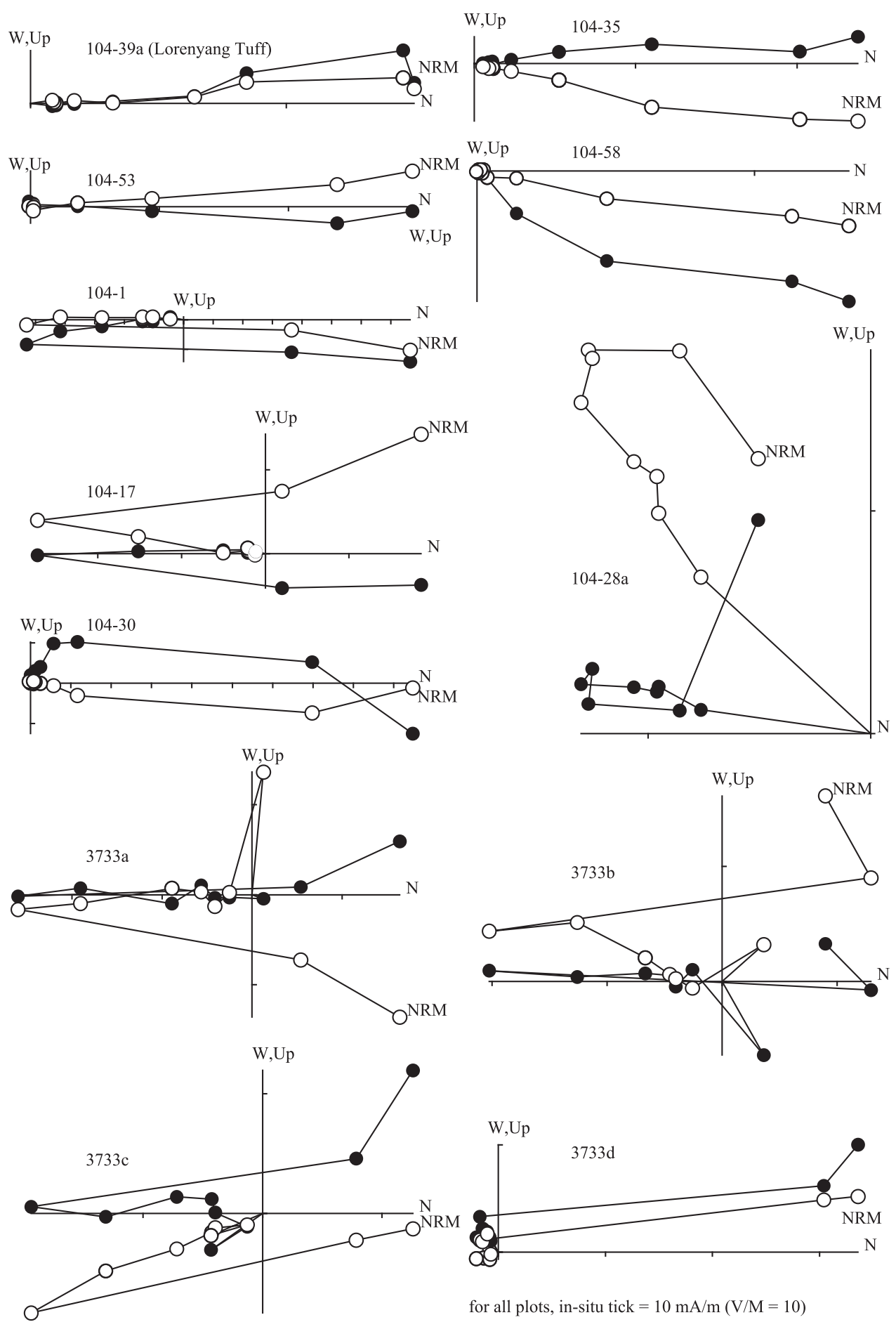

for all plots, in-situ tick $=10 \mathrm{~mA} / \mathrm{m}(\mathrm{V} / \mathrm{M}=10)$

Figure 6. Vector end-point plots of NRM thermal demagnetization (TD) data for representative specimens (as labeled) from the Area 104 section (see Fig. 8 for stratigraphic positions). Open and closed symbols represent the vertical and horizontal projections, respectively, in bedding coordinates. TD treatment steps after NRM: $100^{\circ}, 150^{\circ}, 200^{\circ}, 250^{\circ}$, $300^{\circ}, 350^{\circ}, 400^{\circ}, 450^{\circ}, 500^{\circ}, 525^{\circ}, 550^{\circ}$ and $575^{\circ} \mathrm{C}$.

Roebroeks, 2005; Wood, 2011; Lordkipanidze et al., 2013). A traditional view is that this taxon originated in Africa and dispersed throughout the Old World sometime during the Early Pleistocene. Important evidence to support this view derives from Koobi Fora, as represented by a collection of fossils in varying degrees of completeness that date from 2.0 to 1.5 Ma. This collection can be portioned into two sets of fossils based on the observation that some specimens have a geological age of nearly 2.0 Ma, whereas others date much closer to 1.5 Ma. Previously, KNM-ER 3733 at $\sim 1.78$ Ma was placed at a chronostratigraphic position intermediate to these two sets (e.g., Feibel et al., 1989; Antón, 2003, 2012) and considered to be a direct contemporary of the oldest Homo fossils from out-of-Africa sites like Dmanisi and Java (e.g., Swisher et al., 1994; Gabunia et al., 2000). However, our magnetostratigraphic 


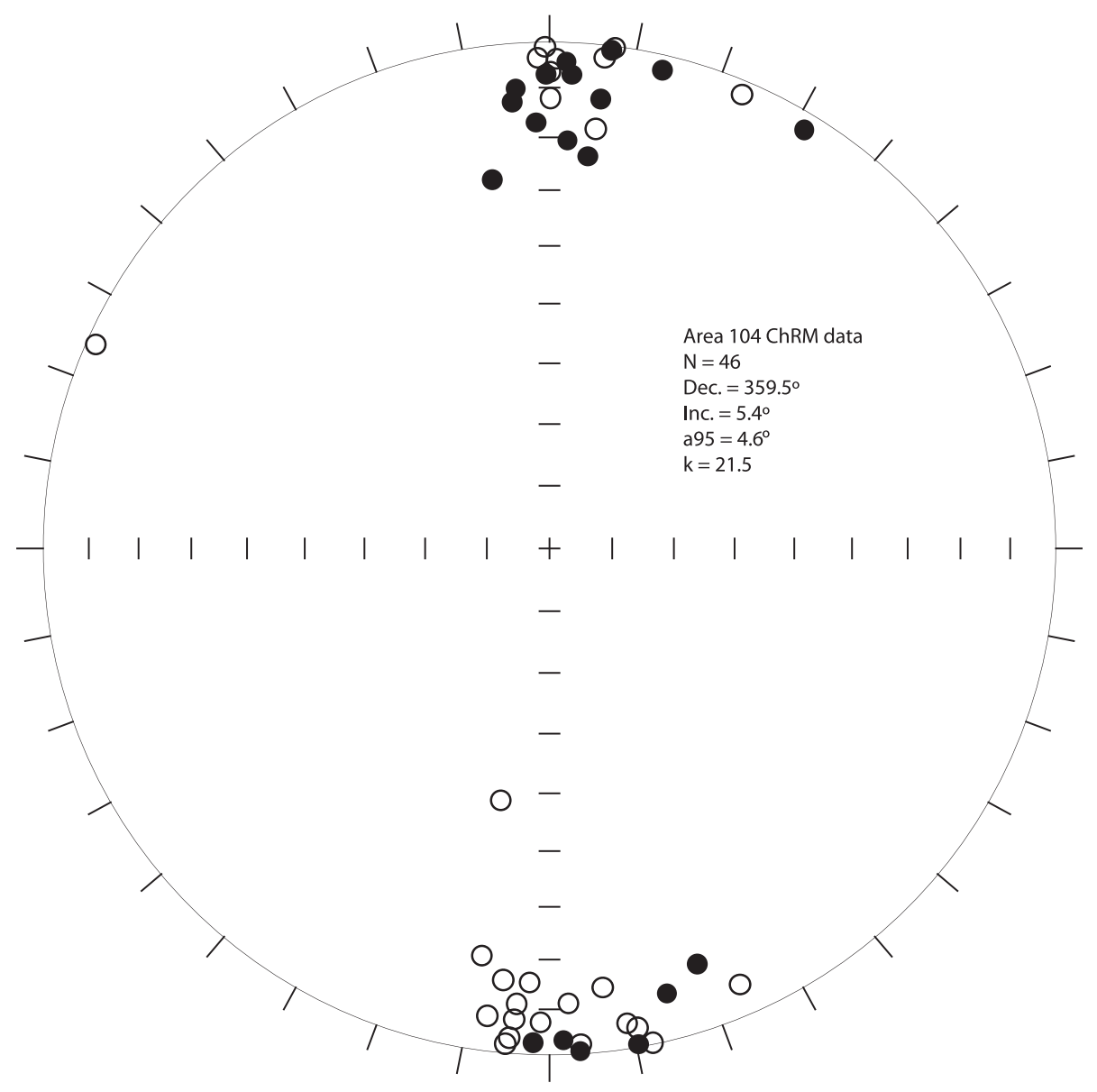

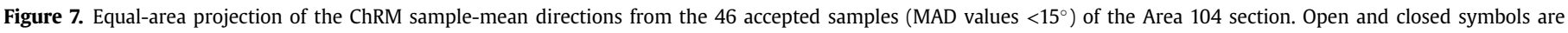
projected onto the upper and the lower hemisphere, respectively, in bedding coordinates.

research now shows that KNM-ER 3733 at $1.63 \mathrm{Ma}$ is better aligned with the geologically younger set of early $H$. erectus fossils from Koobi Fora, including partial crania KNM-ER 3883 and 42700, incomplete skeletons KNM-ER 1808 and 803, and mandible fragments KNM-ER 992, 820 and 730 (Wood, 1991; Antón, 2003, 2012; Spoor et al., 2007; Wood and Baker, 2011; Leakey et al., 2012). Dates for these Koobi Fora specimens fall into the range of 1.6-1.5 Ma (Feibel et al., 1989; Brown et al., 2006; McDougall et al., 2012).

A geologically older set of fossils that includes KNM-ER 2598 and KNM-ER 3228 represents additional yet fragmentary evidence of Early Pleistocene African H. erectus (Wood, 1991, 2011; Antón, 2003, 2012). Some researchers also speculate that KNM-ER 3732 might hint at an early presence of this species (Antón and Swisher, 2004). However, analyses on this second set of fossils do not lend themselves to the interpretation that these fossils are all part of the early African $H$. erectus hypodigm. New fossils and analyses confirm the presence of two contemporary species of early Homo, in addition to H. erectus, in the Early Pleistocene of Koobi Fora, with one of these non- $H$. erectus species partially represented by KNM-ER 3732 (Leakey et al., 2012). Similarly, KNM-ER 3228 might be interpreted better as a post-cranial element belonging to one of the non$H$. erectus taxa (McHenry and Coffing, 2000). Therefore, KNM-ER 2598 perhaps is the only one of these geologically older fossils that potentially represents the earliest first appearance of $H$. erectus in Africa or elsewhere (Wood, 1991; Antón, 2003, 2012). KNM-ER 2598 is an occipital fragment with a torus (Wood, 1991). Some studies describe this as an autapomorphy of Pleistocene $H$. erectus from Africa and Asia (Rightmire, 1998; Antón, 2003). The stratigraphic position of KNM-ER 2598 has been placed at about $4 \mathrm{~m}$ below the KBS Tuff in Area 15 and thus has a geological age of just older than 1.87 Ma (Feibel et al., 1989; McDougall et al., 2012). It thus predates by 200-300 kyr relatively complete $H$. erectus crania KNM-ER 3733, KNM-ER 3883, and KNM-ER 42700, which are geologically younger than several of the specimens from the oldest out-of-Africa sites at Dmanisi (Gabunia et al., 2000; Ferring et al., 2011 ) and Java (Swisher et al., 1994). Therefore, from the perspective of fossil chronostratigraphy, KNM-ER 2598 might be the lone example providing support for the idea that $H$. erectus originated in and dispersed from Africa (Fig. 10).

As intimated by Fig. 10, there is a lack of $H$. erectus fossils from Koobi Fora spanning almost a 300-kyr interval between specimens dating to 1.9 Ma (e.g., KNM-ER 2598) and specimens dating to $\sim 1.6$ Ma (e.g., KNM-ER 3733). This perhaps represents a survey or taphonomic bias, or evidence of an evolutionary process causing initial low population densities at $\sim 1.9$ Ma followed by a density increase at $\sim 1.6 \mathrm{Ma}$. Bobe and Leakey (2009) estimate the uncertainty associated with a hominin first appearance datum (FAD) by considering the abundance of a taxon once it appears in the fossil record, and the abundance and distribution of samples prior to that FAD. The timeframe that constrains the observable FAD of Homo in the Koobi Fora Formation dates to 2.0-1.5 Ma (Feibel et al., 1989; Wood, 1991; Leakey et al., 2012; McDougall et al., 2012). Bobe and Leakey (2009) also point out that this FAD is biased by an unconformity; their estimates suggest that the Homo FAD for the 


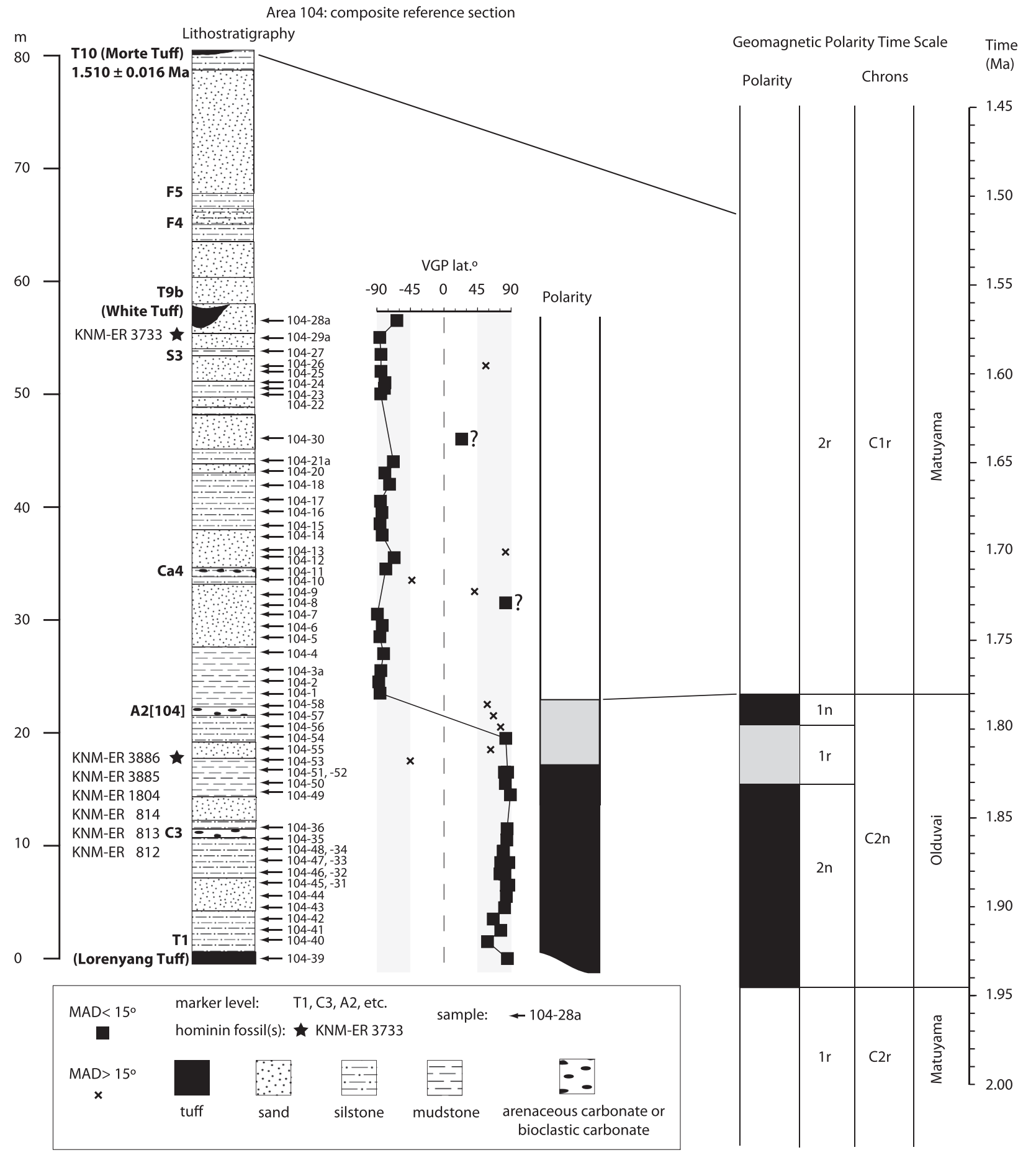

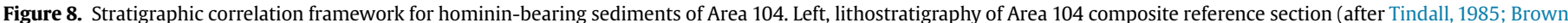

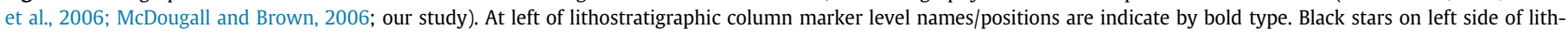

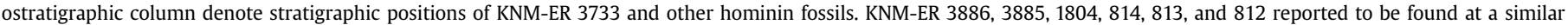

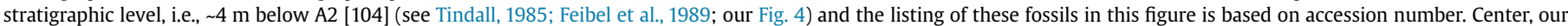

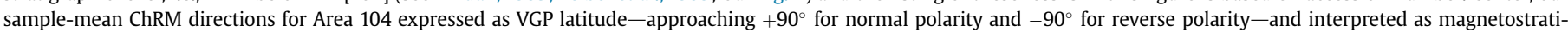

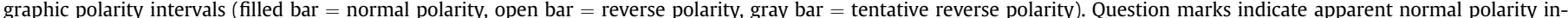

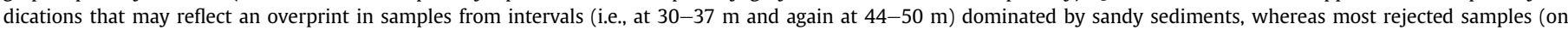

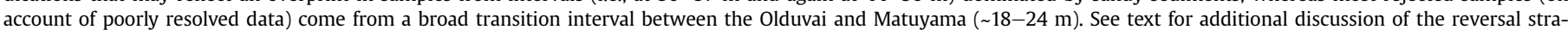
tigraphy and placement of the Olduvai-Matuyama boundary. Right, Geomagnetic Polarity Time Scale (after Lourens et al., 2004).

Koobi Fora Formation might be at 3.0-2.5 Ma. Therefore, it is possible that African $H$. erectus appeared earlier than the FAD represented by KNM-ER 2598. The same can be said about the FAD for the out-of-Africa sites because of the vertically short stratigraphic records associated with the Homo fossils and lithic artifacts (Wood, 2011). However, Acheulian tools may have been the Lower Paleolithic technology that was originated and used exclusively by H. erectus during the Early Pleistocene (Antón, 2003). 

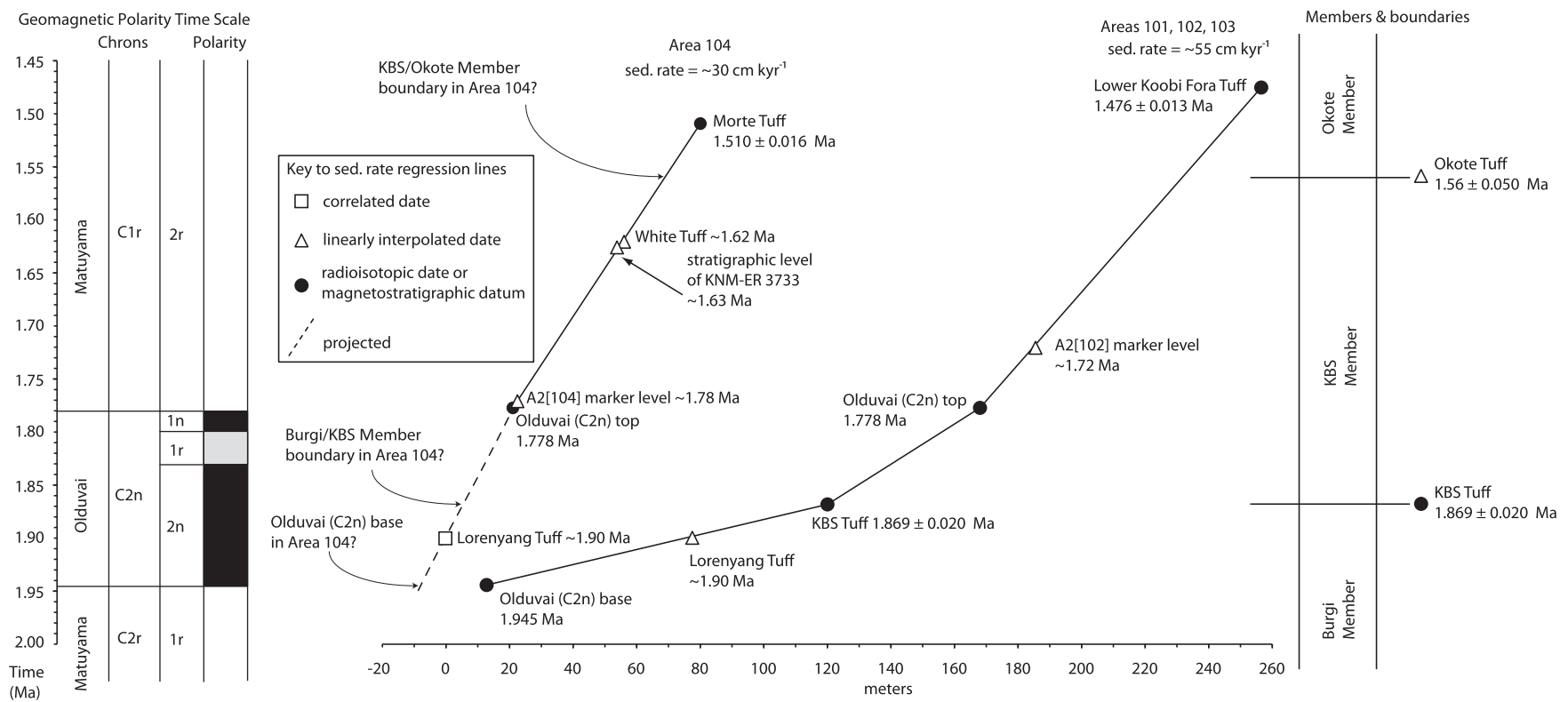

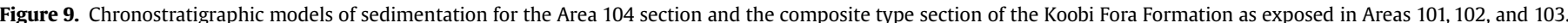

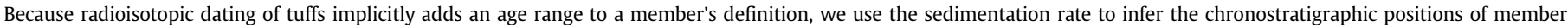

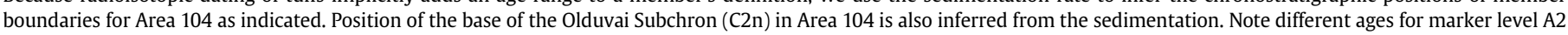
[104] and A2 [102], and the interpolated ages of $~ 1.62$ Ma for the White Tuff and 1.63 Ma for KNM-ER 3733.

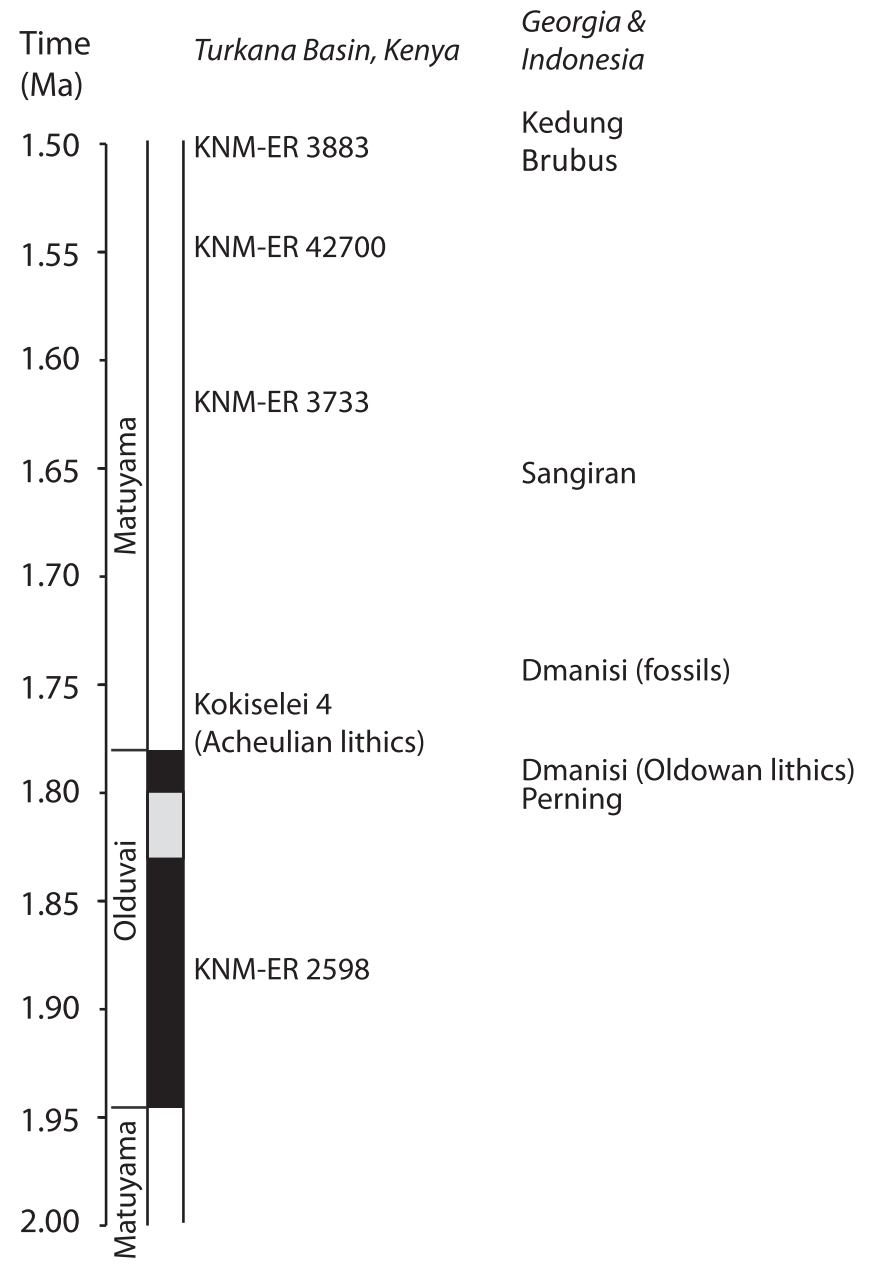

Figure 10. Chronostratigraphic comparison of the principal cranial fossils representative of early $\mathrm{H}$. erectus from Koobi Fora and the oldest out-of-Africa sites with Homo cranial fossils, including the site preserving Oldowan stone tools at Dmanisi. Also included is the Acheulian site of Kokiselei 4 from the Turkana Basin, preserving some of the oldest lithics apparently associated with $H$. erectus in Africa.
Lepre et al. (2011) have demonstrated that the oldest Acheulian tools currently known date to $1.76 \mathrm{Ma}$ and derive from the Kokiselei site in the western Turkana Basin. A similar date has been reported for the earliest Acheulian sites from the Konso Formation of Ethiopia (Beyene et al., 2013). Therefore, if the Acheulian is indeed a proprietary hallmark of $H$. erectus, then nearby hand axes dated at 1.76 Ma help to fill the gap between KNM-ER 2598 and KNM-ER 3733, and might substantiate a somewhat continual presence of this species in northwest Kenya at 1.9-1.6 Ma.

\section{Conclusions}

In Area 104 the stratigraphic position of the Olduvai-Matuyama boundary (1.78 Ma) is virtually coincident with the level of marker bed A2 [104]. Magnetostratigraphic evidence and a paucity of member-defining tuffs indicate complexities for correlating the A2 [104] marker bed and other strata from Area 104 to the Koobi Fora Formation type section in Area 102 where the type occurrence of A2 (designated here as A2 [102]) crops out.

On the basis of similarities between mollusk-packed sandstones, bivalve molds, and algal horizons, Brown and Feibel (1986) and Feibel et al. (1989) correlated A2 [104] to A2 [102]. Note that it is not possible to walk and laterally follow A2 across the $\sim 10 \mathrm{~km}$ of landscape between the two areas because of the discontinuous outcrops. A2 [104] is within the interval of transitional paleomagnetic directions associated with the Olduvai-Matuyama boundary (Fig. 8). This differs from the type section of the KBS Member where Lepre and Kent (2010) identified $\sim 18 \mathrm{~m}$ of reverse polarity section between the top of the Olduvai and the base of A2 [102] (Panel C in Fig. 3). The lack of evident faulting, the amplitude of erosive relief, fine grain sizes, and conformable layering for strata surrounding A2 [104] do not suggest the presence of an unconformity. Thus, A2 [102] and A2 [104] either accumulated diachronously between the two areas or are similar-looking beds that accumulated at distinctively different chronostratigraphic levels. In either case, A2 becomes a problematical marker level for litho- or chrono-stratigraphic correlations across discontinuous outcrops and between the collecting areas of Koobi Fora. Gathogo and Brown (2006) expressed 
similar concerns. Extending A2 correlations across the basin to West Turkana (Roche et al., 2003) also should be met with caution.

The Area 104 magnetostratigraphy provides a means to calculate new and directly interpolated dates for the A2 [104] marker bed, White Tuff, and the hominin fossils KNM-ER 814, 813, 812, $1804,3733,3885$, and 3886. KNM-ER 3733 dates to $1.63 \mathrm{Ma}$ and there is a dearth of $H$. erectus fossils from Koobi Fora that are geologically older. Several of the oldest Homo fossils from out-ofAfrica sites, such as those from Dmanisi and Java, predate most of the $H$. erectus fossils from Koobi Fora, except the fragmentary fossil KNM-ER 2598 that dates to $>1.87$ Ma. An almost 300-kyr gap of $H$. erectus fossils exists between Koobi Fora specimens dating to $>1.87 \mathrm{Ma}$ (e.g., KNM-ER 2598) and Koobi Fora specimens dating to $1.63 \mathrm{Ma}$ (e.g., KNM-ER 3733). This gap may represent an artifact of evolutionary process or a preservation or collection bias. However, if the Acheulian is indeed a proprietary hallmark of $H$. erectus, then hand axes from the Kokiselei site dated at 1.76 Ma help to fill the gap between KNM-ER 2598 and KNM-ER 3733, and might substantiate a somewhat continual presence of this species in northwest Kenya at 1.9-1.6 Ma.

\section{Acknowledgments}

We would like to thank the government of Kenya and the National Museums of Kenya for their support of the research in Koobi Fora. The Koobi Fora Research Project and the Turkana Basin Institute are acknowledged for logistical and financial support that made possible the fieldwork. Frank Brown and Craig Feibel are thanked for discussing their understanding of Area 104. Meave Leakey provided valuable on-the-ground guidance during the fieldwork. Rhonda Quinn, Ian McDougall, and Susan Antón are thanked for reading earlier drafts and providing suggestions to improve the manuscript. The Lamont-Doherty Earth Observatory of Columbia University is acknowledged for the ongoing support of the Paleomagnetics Laboratory. This is Lamont-Doherty Earth Observatory contribution \#7911.

\section{References}

Antón, S.C., 2003. Natural history of Homo erectus. Am. J. Phys. Anthropol. 122 (S37), $126-170$.

Antón, S.C., 2012. Early Homo. Curr. Anthropol. 53, 278-298.

Antón, S.C., Swisher, C.C., 2004. Early dispersals of Homo from Africa. Annu. Rev. Anthropol. 33, 271-296.

Beyene, Y., Katoh, S., WoldeGabriel, G., Hart, W.K., Uto, K., Sudo, M., Kondo, M., Hyodo, M., Renne, P.R., Suwa, G., Asfaw, B., 2013. The characteristics and chronology of the earliest Acheulean at Konso, Ethiopia. Proc. Natl. Acad. Sci. $110,1584-1591$.

Bobe, R., Leakey, M.G., 2009. Ecology of Plio-Pleistocene mammals in the OmoTurkana Basin and the emergence of Homo. In: Grine, F.E., Fleagle, J.G., Leakey, R.E. (Eds.), The First Humans-Origin and Early Evolution of the Genus Homo. Springer, Netherlands, pp. 173-184.

Brown, F.H., Feibel, C.S., 1986. Revision of lithostratigraphic nomenclature in the Koobi Fora region, Kenya. J. Geol. Soc. 143, 297-310.

Brown, F.H., Feibel, C.S., 1991. Stratigraphy, depositional environments and palaeogeography of the Koobi Fora Formation. In: Harris, J. (Ed.), Koobi Fora Research Project, Volume 3. Claredon, Oxford, pp. 1-30.

Brown, F.H., Haileab, B., McDougall, I., 2006. Sequence of tuffs between the KBS Tuff and the Chari Tuff in the Turkana Basin, Kenya and Ethiopia. J. Geol. Soc. 163, 185-204.

Clement, B.M., Kent, D.V., 1987. Geomagnetic polarity transition records from five hydraulic piston core sites in the North Atlantic. Initial. Rep. Deep Sea 94, 831-852.

Dennell, R., Roebroeks, W., 2005. An Asian perspective on early human dispersal from Africa. Nature 438, 1099-1104.

Feibel, C.S., Brown, F.H., McDougall, I., 1989. Stratigraphic context of fossil hominids from the Omo group deposits: Northern Turkana Basin, Kenya and Ethiopia. Am. J. Phys. Anthropol. 78, 595-622.

Ferring, R., Oms, O., Agustí, J., Berna, F., Nioradze, M., Shelia, T., Tappen, M., Vekua, A., Zhvania, D., Lordkipanidze, D., 2011. Earliest human occupations at Dmanisi (Georgian Caucasus) dated to 1.85-1.78 Ma. Proc. Natl. Acad. Sci. 108, 10432-10436.
Gabunia, L., Vekua, A., Lordkipanidze, D., Swisher, C.C., Ferring, R., Justus, A., Nioradez, M., Tvalchrelidze, M., Antón, S., Bosinski, G., Joris, O., de Lumley, M.A. Majsuradze, G., Mouskhelishvili, A., 2000. Earliest Pleistocene hominid crania remains from Dmanisi, Republic of Georgia: taxonomy, geological setting, and age. Science 288, 1019-1025.

Gathogo, P.N., Brown, F.H., 2006. Revised stratigraphy of Area 123, Koobi Fora, Kenya, and new age estimates of its fossil mammals, including hominins. J. Hum. Evol. 51, 471-479.

Heller, F., Liu, X., Liu, T.S., Xu, T., 1991. Magnetic susceptibility of loess in China. Earth Planet. Sci. Lett. 103, 301-310.

Hillhouse, J.W., Ndombi, J.W.M., Cox, A., Brock, A., 1977. Additional results on palaeomagneticstratigraphy of the Koobi Fora Formation, east of Lake Turkana (Lake Rudolf), Kenya. Nature 265, 411-415.

Hillhouse, J.W., Cerling, T.E., Brown, F.H., 1986. Magnetostratigraphy of the Koobi Fora Formation, Lake Turkana, Kenya. J. Geophys. Res. 91 (B11) $11581-11595$.

Holt, J.W., Kirschvink, J.L., 1995. The upper Olduvai geomagnetic field reversal from Death Valley, California: a fold test of transitional directions. Earth Planet. Sci. Lett. 133, 475-491.

Joordens, J.C., Vonhof, H.B., Feibel, C.S., Lourens, L.J., Dupont-Nivet, G., van de Lubbe, J.H., Sier, M.J., Davies, G.R., Kroon, D., 2011. An astronomically-tuned climate framework for hominins in the Turkana Basin. Earth Planet. Sci. Lett. 307, $1-8$

Kidane, T., Courtillot, V., Manighetti, I., Audin, L., Lahitte, P., Quidelleur, X., Gillot, P. Y., Gallet, Y., Carlut, J., Haile, T., 2003. New paleomagnetic and geochronologic results from Ethiopian Afar: Block rotations linked to rift overlap and propagation and determination of a 2 Ma reference pole for stable Africa. J. Geophys. Res. 108, 2102.

Kirschvink, J.L., 1980. The least-squares line and plane and the analysis of palaeomagnetic data. Geophys. J. Int. 62, 699-718.

Kruiver, P.P., Dekkers, M.J., Heslop, D., 2001. Quantification of magnetic coercivity components by the analysis of acquisition curves of isothermal remanent magnetisation. Earth Planet. Sci. Lett. 189, 269-276.

Leakey, M.G., Leakey, R.E., 1978. Koobi Fora Research Project Volume 1. Clarendon Press, Oxford.

Leakey, M.G., Spoor, F., Dean, M.C., Feibel, C.S., Antón, S.C., Kiarie, C., Leakey, L.N. 2012. New fossils from Koobi Fora in northern Kenya confirm taxonomic diversity in early Homo. Nature 488, 201-204.

Lepre, C.J., 2014. Early Pleistocene lake formation and hominin origins in the Turkana-Omo rift. Quatern. Sci. Rev. 102, 181-191.

Lepre, C.J., Kent, D.V., 2010. New magnetostratigraphy for the Olduvai Subchron in the Koobi Fora Formation, northwest Kenya, with implications for early Homo. Earth Planet. Sci. Lett. 290, 362-374.

Lepre, C.J., Quinn, R.L., Joordens, J.C.A., Swisher, C.C., Feibel, C.S., 2007. Plio-Pleistocene facies environments from the KBS Member, Koobi Fora Formation: implications for climate controls on the development of lake-margin hominin habitats in the northeast Turkana Basin (northwest Kenya). J. Hum. Evol. 53, 504-514.

Lepre, C.J., Roche, H., Kent, D.V., Harmand, S., Quinn, R.L., Brugal, J.P., Lenoble, A., Texier, P.-J., Feibel, C.S., 2011. An earlier origin for the Acheulian. Nature 477 $82-85$.

Lordkipanidze, D., de León, M.S.P., Margvelashvili, A., Rak, Y., Rightmire, G.P., Vekua, A., Zollikofer, C.P., 2013. A complete skull from Dmanisi, Georgia, and the evolutionary biology of early Homo. Science 342, 326-331.

Lourens, L.J., Hilgen, FJ., Shackleton, N.J., Laskar, J., Wilson, D., 2004. The Neogene period. In: Gradstein, F.M., Ogg, J.G., Smith, A.G. (Eds.), A Geologic Time Scale 2004. Cambridge University, Cambridge, pp. 409-440.

McDougall, I., Brown, F.H., 2006. Precise ${ }^{40} \mathrm{Ar} /{ }^{39} \mathrm{Ar}$ geochronology for the upper Koobi Fora Formation, Turkana Basin, northern Kenya. J. Geol. Soc. 163, 205-220.

McDougall, I., Brown, F.H., Cerling, T.E., Hillhouse, J.W., 1992. A reappraisal of the geomagnetic polarity time scale to $4 \mathrm{Ma}$ using data from the Turkana Basin, East Africa. Geophys. Res. Lett. 19, 2349-2352.

McDougall, I., Brown, F.H., Vasconcelos, P.M., Cohen, B.E., Thiede, D.S, Buchanan, M.J., 2012. New single crystal ${ }^{40} \mathrm{Ar} /{ }^{39} \mathrm{Ar}$ ages improve time scale for deposition of the Omo Group, Omo-Turkana Basin, East Africa. J. Geol. Soc. 169, 213-226.

McFadden, P.L., McElhinny, M.W., 1990. Classification of the reversal test in palaeomagnetism. Geophys. J. Int. 103, 725-729.

McHenry, H.M., Coffing, K., 2000. Australopithecus to Homo: transformations in body and mind. A. Rev. Anthropol. 29, 125-146.

Ninkovich, D., Opdyke, N.D., Heezen, B.C., Foster, J.H., 1966. Paleomagnetic stratigraphy, rates of deposition and tephrachronology in North Pacific deep-sea sediments. Earth Planet. Sci. Lett. 1, 476-492.

Rightmire, G.P., 1998. Evidence from facial morphology for similarity of Asian and African representatives of Homo erectus. Am. J. Phys. Anthropol. 106 $61-85$.

Roche, H., Brugal, J.P., Delagnes, A., Feibel, C., Harmand, S., Kibunjia, M., Prat, S. Texier, P.-J., 2003. Plio-Pleistocene archaeological sites in the Nachukui Formation, West Turkana, Kenya: synthetic results 1997-2001. C. R. Palevol. 8, 663-673.

Spoor, F., Leakey, M.G., Gathogo, P.N., Brown, F.H., Antón, S.C., McDougall, I., Kiarie, C., Manthi, F.K., Leakey, L.N., 2007. Implications of new early Homo fossils from Ileret, east of Lake Turkana, Kenya. Nature 448, 688-691. 
Swisher, C.C., Curtis, G.H., Jacob, T., Getty, A.G., Suprijo, A., 1994. Age of the earliest known hominids in Java, Indonesia. Science 263, 1118-1121.

Tauxe, L., Opdyke, N.D., Pasini, G., Elmi, C., 1983. Age of the Plio-Pleistocene boundary in the Vrica section, southern Italy. Nature 304, 125-129.

Tindall, K.W., 1985. Stratigraphy and sedimentology of the Koobi Fora Formation, eastern Koobi Fora Ridge, East Turkana, Kenya. M.Sc. Thesis, Iowa State University.

Tric, E., Laj, C., Jehanno, C., Valet, J.-P., Kissel, C., Mazaud, A., Iaccarino, S., 1991. Highresolution record of the upper Olduvai transition from Po Valley (Italy) sediments-support for dipolar transition geometry. Phys. Earth Planet. 65, 319-336.

Wood, B.A., 1974. Evidence on the locomotor pattern of Homo from early Pleistocene of Kenya. Nature 251, 135-136.
Wood, B.A., 1991. Hominid cranial remains. Koobi Fora Research Project, Volume 4. Clarendon Press, Oxford.

Wood, B., 2011. Did early Homo migrate “out of" or "in to" Africa? Proc. Natl. Acad. Sci. 108, 10375-10376

Wood, B., Baker, J., 2011. Evolution in the genus Homo. Annu. Rev. Ecol. Evol. Syst. 42, 47-69.

Wood, B., Constantino, P., 2007. Paranthropus boisei: fifty years of evidence and analysis. Am. J. Phys. Anthropol. 134 (S45), 106-132.

Zijderveld, J.D.A., Hilgen, FJ. Langereis, C.G., Verhallen, P.J.M., Zachariasse, W.J. 1991. Integrated magnetostratigraphy and biostratigraphy of the upper Pliocene-lower Pleistocene from the Monte Singa and Crotone areas in Calabria, Italy. Earth Planet. Sci. Lett. 107, 697-714. 